Ольга Красницька, кандидат педагогічних наук Національний університет оборони України імені Івана Черняховського ORCID ID 0000-0002-0417-3318 DOI 10.33099/2617-1775/2019-01/133-141

\title{
ОРАТОРСЬКЕ МИСТЕЦТВО В СИСТЕМІ ПРОФЕСІЙНОЇ ПІДГОТОВКИ ВІЙСЬКОВОГО КЕРІВНИКА
}

У статті окреслено значення ораторського мистецттва в діяльності офіцера, обтрунтовано роль і місце навчальної дисципліни «Основи ораторського мистецтва та риторичної комунікації» в системі професійної підготовки військового керівника. Визначено мету й завдання курсу, представлено знання та вміння, які здобуває слухач у результаті його вивчення. Описано зміст аудиторної та самостійної роботи, надано детальну характеристику лекиійним, груповим, практичним і семінарським заняттям із дисиипліни. Відзначено вивчення офіцерами чотирьох тем: теоретичні основи ораторського мистецтва, риторична культура офічера, майстерність підготовки та проведення публічного виступу, інтерв'ю офічера. Визначено практичне спрямування дисципліни.

Ключові слова: риторика; ораторське мистецтво; публічний виступ; публічна промова; оратор; офіиер; військовий керівник.

Постановка проблеми. Швидкоплинний розвиток інформаційного суспільства, курс України в НАТО вимагають від сучасного військового керівника володіння не лише високим рівнем професійних знань та вмінь, а й умінням спілкуватися з будь-якою категорією населення, ефективно впливати на підлеглих, віддавати накази, агітувати, мотивувати, вести за собою. Публічний виступ $є$ важливою складовою професійної діяльності офіцера. Володіння словом дає йому можливість красиво й зрозуміло говорити, переконувати, відстоювати свої погляди, наказувати, надихати, ухвалювати необхідні рішення, перемагати в полеміці, керувати. Арістотель писав: «Слово - найсильніша зброя людини». Проте, щоб ним правильно користуватися, потрібно навчатися ораторському мистецтву.

Аналіз останніх досліджень і публікацій. Фундаментальні основи ораторського мистецтва було закладено ще у Стародавній Греції та Римі. Оратори виступали на судових процесах, зібраннях, форумах, тому володіння ним вважалося необхідним будь-якому громадському діячу, філософу, судді, полководцю. Воно входило в сім вільних мистецтв, вивчення яких було обов’язковим. До нашого часу дійшли відомі трактати Арістотеля «Риторика» та Цицерона «Про ораторське мистецтво».

Сучасні дослідники приділяють увагу здебільшого вивченню риторики у філософському (В. Вандишев, М. Кащей, О. Марченко, М. Препотенська, С. Шкіль), педагогічному (Н. Голуб, Г. Сагач, Л. Ткаченко), політичному (Ю. Харченко), філологічному (А. Артюхова, К. Ушакова), культурологічному (О. Гончарова), юридичному (С. Володіна, Н. Загребельна, О. Олійник) аспектах. Питання ораторської майстерності досліджують Л. Айдінова, Ю. Дишлюк, Л. Литовченко, О. Михайлова, Є. Тягнирядно; риторичної 
культури - О. Залюбівська; риторичної компетентності - Л. Горобець, О. Кучерук, В. Нищета. Окремі аспекти військової риторики освітлює Ч. Далецький, С. Звєрєв, С. Морозов.

Водночас, аналіз наукових праць засвідчує відсутність досліджень із питання формування та розвитку ораторської майстерності військового керівника.

Мета статті - визначити роль і місце дисципліни «Основи ораторського мистецтва та риторичної комунікації» в системі професійної підготовки військового керівника».

Методи дослідження: аналіз, синтез, порівняння і систематизація наукових джерел, аналіз програмного забезпечення освітнього процесу.

Виклад основного матеріалу. Ораторське мистецтво своїм корінням сягає глибин античності. Уміння говорити завжди було неоціненним для людини. Філософ не зміг би донести своє вчення без знань риторики (науки про ораторське мистецтво), полководець не переконав би людей іти в бій, суддя не зміг би аргументовано висунути звинувачення. Перші школи риторики з'явилися ще у Древній Греції, а тренінги з ораторського мистецтва сьогодні набувають усе більшої популярності. А. Чехов писав: «І в давнину, і в новітній час ораторство було одним із найсильніших важелів культури».

Сьогодні в умовах інформаційного суспільства ефективне спілкування, уміння виступати, вести переговори, управляти виходить на перший план. Людина, яка хоче навчитися ефективно говорити, вести бесіду чи дискусію, перемагати в полеміці, апелювати до почуттів, емоцій та логіки співрозмовника чи аудиторії, переконувати навчається ораторському мистецтву.

Сучасний військовий керівник - це офіцер-лідер, який має вміти спілкуватися 3 особовим складом не лише за допомогою наказів, а говорити ефективно - упевнено, переконливо, аргументовано, чітко та зрозуміло, досягати словом серця військовослужбовця. Й. Гете писав: «Говори переконливо: слова і вплив на слухачів прийдуть самі собою». О. Герцен зауважував: «Немає думки, яку не можна було б висловити просто та ясно».

Система військової освіти чомусь залишає поза увагою вивчення риторики. Аналіз навчальних планів підготовки офіцерів тактичного рівня та окремих програм навчальних дисциплін у вищих військових навчальних закладах свідчить про відсутність дисциплін «Ораторське мистецтво» або «Риторика» у їхній підготовці. Окремий модуль під назвою «Військова риторика» вивчається в контексті дисципліни «Українська мова за професійним спрямуванням». Ми переконані в тому, що цього недостатньо для оволодіння ораторським мистецтвом майбутньому офіцерові.

Аналіз навчальних планів підготовки офіцерів оперативно-тактичного та оперативно-стратегічного рівнів свідчить про відсутність вище названих дисциплін у процесі професійної підготовки військового керівника. Лише офіцери, які навчаються за спеціальністю 254 «Забезпечення військ (сил)», спеціалізацією «Інформаційно-пропагандистське забезпечення військ (сил) та ідеологічна робота у військах» вивчають дисципліну «Основи ораторського 
мистецтва та риторичної комунікації», а також ад’юнкти Національного університету оборони України імені Івана Черняховського - «Педагогічна риторика та культура спілкування». Ці два курси було розроблено нами в авторській редакції, апробовано протягом 2017-2018 та 2018-2019 н. р., отримано позитивні результати.

Ми пропонуємо авторський курс «Основи ораторського мистецтва та риторичної комунікації» до вивчення офіцерам усіх спеціальностей i спеціалізацій, оскільки навчання ораторському мистецтву $\epsilon$ невід'ємною складовою професійної підготовки сучасного військового керівника, здатного не лише наказувати, а й будувати продуктивну взаємодію, ефективно впливати на підлеглий особовий склад, вести за собою.

Ораторське мистецтво - це високий ступінь майстерності публічного виступу, якісна характеристика ораторської мови, майстерне володіння живим словом; мистецтво підготування та виголошування публічної промови 3 конкретною метою дії на слухачів засобами живого слова [2, с. 7].

Публічна промова супроводжує військового керівника щоденно: виголошення наказів, доведення інформації особовому складу, інструктажі, наради, проведення навчальних занять, прес-конференції, інтерв'ю, протокольно-етикетні виступи, а також бесіди, дискусіі, суперечки тощо. Володіння ораторським мистецтвом дасть йому змогу вільно, точно, зрозуміло та обгрунтовано виражати свої думки, за допомогою слова ефективно впливати на особовий склад, слухати й чути співрозмовника, аргументовано доводити свою позицію, думку, бачення, брати участь у дискусіях, перемагати в суперечках, надихати, конструктивно вирішувати професійні питання, володіти риторичною культурою, виступати з промовами різних типів і видів, управляти військовим колективом, підрозділом. Успішність спілкування, сприйняття та розуміння інформації залежить, найперше, від уміння володіти словом. Тож навчання ораторському мистецтву має зайняти одне 3 провідних місць у процесі професійної підготовки військового керівника.

Навчальна дисципліна «Основи ораторського мистецтва та риторичної комунікації» спрямована на оволодіння офіцерами теоретичними основами ораторського мистецтва та розвиток ораторських умінь військового керівника. Вона містить огляд основних питань взаємодії оратора з аудиторією, підготовки та виголошення публічної промови, риторичної культури офіцера, підготовки й проведення інтерв'ю.

Завданнями викладання курсу є такі:

1. Ознайомлення з типами та видами публічних промов, вимогами до них.

2. Опанування методикою підготовки, виголошення та аналізу публічної промови.

3. Розвиток риторичної культури офіцера.

4. Набуття основних операційних навичок, оволодіння ораторськими прийомами й техніками.

У результаті вивчення навчальної дисципліни офіцер повинен

знати: 
- основні принципи ораторського мистецтва, загальні вимоги до публічної промови;

- характеристику типів і видів публічних промов, вимоги до них;

- техніки ораторського виступу;

- проблеми взаємодії оратора й аудиторії;

- вимоги до мовлення офіцера;

- умови ефективності застосування невербальних засобів комунікації в публічному виступі;

- характеристику репрезентативних систем людини;

- етапи підготовки публічного виступу;

- техніки подолання хвилювання перед виступом;

- структуру публічної промови, особливості побудови іiі вступної, основної та заключної частин;

- методику аналізу публічного виступу;

- характеристику логічної й емоційної аргументації, правила побудови тез, аргументів та аргументації;

- умови ефективності застосування технік привертання уваги в публічному виступі;

- основні аспекти підготовки офіцера до інтерв’ю;

- характеристику запитань, методику відповіді на них;

- особливості відповідей на інформаційні та провокаційні запитання;

уміми:

- визначати тип і вид публічної промови;

- вдало використовувати принципи ораторського мистецтва в публічному виступі;

- давати характеристику цільовій аудиторії, малювати їі портрет;

- володіти технікою мовлення (диханням, голосом, дикцією, орфоепією);

- використовувати закони кінесики та проксеміки в публічному виступі;

- враховувати особливості сприйняття інформації під час побудови публічної промови;

- долати почуття невпевненості та хвилювання до виступу, керувати психо-емоційним станом під час нього;

- оформлювати текстовий матеріал виступу, готувати презентацію в PowerPoint;

- визначати мету публічної промови, будувати матрицю цілей;

- структурувати виступ, добирати актуальний і цікавий матеріал;

- готувати інформаційні, переконувальні, протокольно-етикетні виступи;

- переконувати, вибудовувати правильну лінію аргументації;

- добирати найефективніші техніки ораторського виступу й привертання уваги, зацікавлювати, утримувати увагу слухачів протягом усього виступу;

- аналізувати публічну промову;

- вести полеміку; 
- відповідати на інформаційні та провокаційні запитання;

- зробити виступ цікавим, захоплюючим і мотивуючим для слухачів.

Аудиторна робота передбачає розгляд теоретичних питань, виконання вправ на розвиток техніки мовлення, виголошення публічних промов, їх аналіз та обговорення, перегляд відеороликів. Самостійна робота спрямована на виконання творчих завдань: перегляд та аналіз фільмів, відеороликів, підготовка публічних виступів за визначеними темами, складання матриці цілей, опрацювання першоджерел, написання звітів, підготовка есе, аналіз публічних промов відомих ораторів, що ввійшли у список тих, які змінили світ, виконання вправ на розвиток техніки мовлення.

Для ефективної підготовки слухачів до навчальних занять нами було підготовлено практикум «Основи ораторського мистецтва та риторичної комунікації» [1], у якому відображено тематичний план навчальної дисципліни для слухачів очної й заочної форм навчання, завдання для самостійної роботи до кожного навчального заняття, методичні вказівки щодо їх виконання, рекомендовану літературу, публічні промови відомих ораторів, вимоги до есе й контрольної роботи, вимоги до диференційованого заліку, навчальнометодичну картку дисципліни, критерії оцінювання результатів освітньої діяльності, тести для самоконтролю знань.

Курс «Основи ораторського мистецтва та риторичної комунікації» передбачає вивчення чотирьох тем, а саме: теоретичні основи ораторського мистецтва, риторична культура офіцера, майстерність підготовки та проведення публічного виступу, інтерв'ю офіцера.

Тема «Теоретичні основи ораторського мистецтва» містить три заняття. Лекція «Ораторське мистецтво в діяльності офіцера» передбачає обгрунтування ролі й місця ораторського мистецтва в діяльності офіцера, розгляд його принципів, обговорення сутності, мети, завдань публічної промови й основних вимог до неї.

Практичне заняття «Особливості публічних промов різних типів» має на меті розбір типів і видів публічних промов, виявлення особливостей інформаційних, переконувальних, протокольно-етикетних та розважальних виступів. Підготовка й виголошення слухачем інформаційної промови дає змогу зробити первинну оцінку його ораторських умінь, проаналізувати поведінку перед аудиторією.

Групове заняття «Взаємодія оратора й аудиторії» присвячено розгляду питань сутності та проблем взаємодії оратора з аудиторією, портрету аудиторії, виявленню ключових ознак, які необхідно обов'язково враховувати при іiі характеристиці, а також обговоренню технік ораторського виступу.

Тема «Риторична культура офіцера» містить шість занять. На лекції «Культура мовлення офіцера» обговорюються вимоги до мовлення офіцера, детально розбирається питання техніки мовлення, культури слухання, а також окремо розглядається голос як інструмент оратора.

Практичні заняття 3 теми «Техніка мовлення» спрямовані на розвиток техніки мовлення офіцера й передбачають виконання вправ на дихання, 
артикуляцію, дикцію, а також правильність і виразність мовлення. На занятті слухачі опановують вправи, які зможуть в подальшому виконувати самостійно та вдосконалювати власну культуру мовлення.

Практичне заняття «Голос як основний інструмент роботи оратора» має на меті розвиток техніки мовлення офіцера, тренування інтонаційності мовлення, розвиток гнучкості голосу.

Групове заняття «Невербальна поведінка офіцера під час публічного виступу» присвячено характеристиці засобів невербальної поведінки, а саме: зовнішнього вигляду, жестів, міміки, пози, постави, візуального контакту та просторово-часової дистанції, а також визначенню правил використання законів кінесики й проксеміки під час взаємодії оратора з аудиторією. На занятті окреслюється використання засобів невербальної поведінки не лише під час публічного виступу, а й у професійній діяльності та повсякденному житті.

Практичне заняття «Сприйняття інформації як чинник успішного публічного виступу» передбачає обговорення репрезентативних систем людини, визначення особливостей їх використання в публічному виступі 3 метою досягнення повного сприйняття та розуміння слухачами інформації, бажаного впливу на аудиторію та мети виступу. Виголошення публічної промови з урахуванням репрезентативних систем дає змогу закріпити отриману інформацію на практиці.

Тема «Майстерність підготовки та проведення публічного виступу» містить сім занять. Лекція «Теоретичні аспекти підготовки офіцера до публічного виступу» присвячена розгляду етапів підготовки публічної промови, обговоренню почуття невпевненості та страху перед виступом, значення хвилювання, а також способів його подолання.

Практичне заняття 3 теми «Практичні аспекти підготовки офіцера до публічного виступу» передбачає розгляд питання оформлення текстового матеріалу промови, особливостей підготовки презентації в PowerPoint, визначення іï помилок. Підготовка матриці цілей спрямована на розвиток уміння ставити цілі публічного виступу, ураховувати як мету оратора, так і цілі аудиторії.

Практичні заняття «Структура публічної промови» спрямовані на отримання теоретичних знань щодо правильної побудови виступу, виявлення відмінностей інформаційної й переконувальної промов, особливостей їх вступної, основної та заключної частин. Аналіз слухачами промови президента Європейської ради Дональда Туска «Немає Європи без України», виголошеної у Верховній Раді 19 лютого 2019 року дає змогу їм поглибити теоретичні знання з теми, детально розібрати структуру його промови, виявити плюси та недоліки, відпрацювати уміння аналізувати публічний виступ. Підготовка й виголошення інформаційної та переконувальної промов із теми за вибором офіцера спрямована на розвиток ораторських умінь, а саме: уміння структурувати виступ, підбирати актуальний i цікавий матеріал, використовувати засоби невербальної поведінки, установлювати контакт та зацікавлювати аудиторію, будувати аргументацію, аналізувати виступ. Під час 
публічної промови слухачі відпрацьовують вступну, основну й заключну пї частини, дають зворотний зв'язок один одному. Під час перегляду відео свого виступу вони мають змогу його проаналізувати, визначити недоліки та шляхи їх подолання.

Практичні заняття $з$ теми «Особливості побудови аргументації у виступі офіцера» передбачають визначення правил формулювання тези виступу, підбір аргументів, порядок їх подачі, побудову лінії аргументації, відпрацювання цього на практиці. «Золоті» правила ефективного переконання дають змогу слухачам підсумувати отриману інформацію. Передбачається аналіз відомої публічної промови адмірала Вільяма Г. Макрейвена «Якщо ви хочете змінити світ, спочатку застеліть своє ліжко». Підготовка й виголошення двох публічних промов на основі логічної та емоційної аргументації спрямована на розвиток уміння переконувати, аргументувати свою думку, бачення, відстоювати позицію, а також структурувати виступ, зацікавлювати й тримати увагу аудиторії. Звертається особлива увага на ефективність вступної та заключної частин промови, правильність побудови лінії аргументації в основній частині. Аналіз публічних виступів слухачами навчає їх звертати увагу на тонкощі промови.

Семінарське заняття «Шляхи забезпечення ефективності публічного виступу» має на меті обговорення питань зацікавленості слухачів як психологічної умови успішності публічної промови, активності аудиторії, використання технік привертання уваги, а також висвітлення критеріїв аналізу виступу.

Тема «Інтерв’ю офіцера» містить чотири заняття. Лекція «Підготовка офіцера до інтерв'ю» передбачає розгляд основних аспектів підготовки військового керівника до інтерв'ю та його змісту. Слухачі отримують цінну інформацію про те, як правильно давати інтерв'ю, яких помилок слід уникати, на що необхідно звертати особливу увагу.

Групове заняття «Мистецтво полеміки офіцера» має на меті характеристику запитань, які можуть бути задані журналістом або слухачами під час публічного виступу, їх класифікацію, визначення особливостей відповіді на різні види запитань, а також механізм правильної відповіді на них.

На груповому занятті з теми «Прийоми й техніки проведення інтерв’ю» обговорюється робота з переконаннями журналіста, техніки відповідей на його запитання, зокрема провокаційні.

Практичне заняття «Особливості полеміки в публічному виступі офіцера» спрямоване на розвиток ораторських умінь через підготовку й виголошення публічної промови на тему за вибором офіцера, відпрацювання механізму відповіді на запитання, використання технік відходу від провокаційних запитань, аналіз промови. На ньому обговорюються результати публічних виступів слухачів.

Обов’язковим для офіцерів є написання контрольної роботи «Шляхи формування ораторської майстерності». Головними іiі завданнями $\epsilon$ узагальнити, повторити й закріпити отримані знання; з'ясувати стан 
розвиненості ораторських умінь слухача; визначити офіцером шляхи, методи, засоби подальшого самовдосконалення й формування ораторської майстерності; мотивувати слухача до розвитку та самовдосконалення.

Диференційований залік має на меті оцінювання результатів вивчення дисципліни «Основи ораторського мистецтва та риторичної комунікації», теоретичних знань і практичних умінь офіцерів, рівня розвитку їх ораторських умінь. Він складається 3 теоретичної частини, що передбачає фронтальне опитування за темами всіх навчальних занять, та практичної - публічний виступ, відповіді на запитання, аналіз промови колеги.

Висновки та перспективи подальших досліджень. Вивчення навчальної дисципліни «Основи ораторського мистецтва та риторичної комунікації» дасть змогу військовому керівнику здобути риторичні знання, що складуть фундамент успішних публічних виступів, розвинути основні ораторські вміння, сформувати риторичну культуру. Відпрацювання практичних завдань, зокрема підготовки й виголошення публічних промов різних типів і видів, їх аналіз, робота $з$ аудиторією дасть можливість розвинути культуру мислення, культуру мовлення, сформувати навички публічного спілкування, розуміти й бути зрозумілим підлеглими, будувати продуктивну з ними взаємодію, ефективно керувати військовим колективом, підрозділом, вирішувати професійні завдання, проводити наради, виступати на конференціях, давати інтерв'ю.

Перспективами подальших досліджень $є$ розробка анкет та тестів, спрямованих на визначення рівня розвитку ораторських умінь військового керівника, а також написання конспекту лекцій із дисципліни «Основи ораторського мистецтва та риторичної комунікації».

\section{ЛІТЕРАТУРА}

1. Красницька Ольга. Основи ораторського мистецтва та риторичної комунікації : практикум. Київ : ЦП «КОМПРИНТ», 2019. 110 с.

2. Ораторське мистецтво : підручник / М. П. Требін та ін. ; за ред. М. П. Требіна, Г. П. Клімової. 2-ге вид. Харків : Право, 2015. 208 с.

\section{REFERENCES}

1. Krasnytska Olha (2019) Osnovy oratorskoho mystetstva ta rytorychnoi komunikatsii [Basis of Public Speaking and Rhetorical Communication] : praktykum. Kyiv : TsP «KOMPRYNT». $110 \mathrm{~s}$.

2. Oratorske mystetstvo [Public Speaking] : pidruchnyk (2015) / M. P. Trebin ta in. ; za red. M. P. Trebina, H. P. Klimovoi. 2-he vyd. Kharkiv : Pravo. 208 s.

\section{PEЗЮME}

Ольга Красницкая, кандидат педагогических наук Национальный университет обороны Украины имени Ивана Черняховского

Ораторское искусство в системе профессиональной подготовки военного руководителя

В статье обозначено значение ораторского искусства в деятельности офицера, обосновано роль и место учебной дисииплинь «Основы ораторского искусства $и$ риторической коммуникации» в системе профессиональной подготовки военного руководителя. Определень цеели и задачи курса, представлены знания и умения, которые 
приобретает слушатель в результате его изучения. Описано содержание аудиторной и самостоятельной работы, предоставлено подробную характеристику лекционным, групповым, практичным и семинарским занятиям по дисциплине. Отмечено изучение офицерами четырех тем: теоретические основы ораторского искусства, риторическая культура офицера, мастерство подготовки и проведения публичного выступления, интервью офицера. Определено практическое направление дисциплинь.

Ключевые слова: риторика; ораторское искусство; публичное выступление; публичная речь; оратор; офіцер; военный руководитель.

\title{
SUMMARY
}

\author{
Olha Krasnytska, \\ Candidate of Pedagogical Sciences \\ National University of Defense of Ukraine \\ named after IvanChernyakhovskyi
}

\section{The Art of Rhetoric in the System of Professional Training of Military Leader}

Introduction. The high-speed development of informational society, Ukraine's course for NATO demands from modern military leader not only high level of professional knowledges and skills, but also skills to communicate with every category of citizens, effecticly to influence on subordinates, to give orders, to agitate, to motivate and to lead. The public speech is an important part of professional activity of officer. It gives him an opportunity to speak beautifully and understandable, to defend the notion, to order, to inspire, to make a necessary decision, to win in polemics, to rule. But in order to use it right, one should study the art of rhetoric.

Purpose is to define role and place of the course "The Basics of the art of rhetoric and rhetorical communication» in the system of professional training of military leader.

Methods: analysis, synthesis, comparison and systematization of scientific sources, analysis of program support of educational process.

Results. The meaning of the art of rhetoric in the officers's activities is described, its role and place of educational course of «The Basics of the art of rhetoric and rhetorical communication» in the system of professional training of military leader is substantiated. The purpose and aims of course is defined and knowledges and skills, which student obtains resulting from study are also presented. The content of in-class work and independent work are described. The detailed characteristics is provided to lectures, group studies, practices and seminar classes of this course. Officers study four themes: theoretical basics of the art of rhetoric, officer's rhetorical culture, proficiency of preparing and performing public speech, officer's interview. The practical focus of this course is determined.

Originality. The description of the auctorial course «The Basics of the art of rhetoric and rhetorical communication» is presented. The characteristics of every class reveals results, obtained by officers at the time of studying this course.

Conclusion. Study of the course «The Basics of the art of rhetoric and rhetorical communication» gives an opportunity for military leader to gain rhetorical knowledges, which form a base for successful public performances, to develop basic rhetorical skills, to form rhetoric culture. Exercising practical tasks such as preparing and performing public speeches of different types, its analysis, work with audience will give an opportunity to develop culture of thinking and speaking, to form skills of public speaking, to understand and to be understandable for colleagues, to build an efficient cooperation with them, to lead the staff, unit effectively, to solve professional tasks, to hold meetings, to speak at conferences, to give interviews.

Key words: rhetoric; the art of rhetoric; public speech; public performance; orator; officer; military leader. 